\title{
ショットキー型熱電界電子源 $\mathrm{Zr} / \mathrm{O} / \mathrm{W}$ の表面分析 ${ }^{\dagger}$
}

\author{
松永 宗一郎・片桐 創一 \\ (株) 日立製作所 中央研究所 正185-8601 東京都国分寺市東恋ヶ寉 1-280
}

（2015 年 2 月 4 日受付；2015 年 3 月 3 日掲載決定)

\section{Surface Analysis of $\mathrm{Zr} / \mathrm{O} / \mathrm{W}$ Schottky Emitter}

Soichiro Matsunaga and Souichi KatagiRI

Central Research Laboratory Hitachi Ltd., 1-280 Higashi-koigakubo, Kokubunji, Tokyo 185-8601

(Received February 4, 2015 ; Accepted March 3, 2015)

\begin{abstract}
$\mathrm{Zr} / \mathrm{O} / \mathrm{W}$ Schottky emitter surface was investigated by using surface analytical techniques. We improved RHEED equipment by installing a heating stage and a micro-imaging system, and surface periodicity on the $\mathrm{Zr} / \mathrm{O} / \mathrm{W}(100)$ and (110) of a Schottky emitter tip have been directly measured. Reversible structural change from $\mathrm{c}(2 \times 4)+\mathrm{c}(4 \times 2)$ to $\mathrm{p}$ $(1 \times 1)$ has been observed only in $(100)$ surface. We also measured initial velocity of the secondary ions by using specialized TOF-SIMS and investigated generation sites of $\mathrm{Zr}$, W, and their oxides. A structural model of a $\mathrm{Zr} / \mathrm{O} / \mathrm{W}$ surface was proposed that $\mathrm{Zr}$ atoms are adsorbed on $\mathrm{O}$ atoms in $\mathrm{W}-\mathrm{O}$ layers formed on the $\mathrm{W}$ single crystal.
\end{abstract}

KEYWORDS : Schottky emitter, Zr/O/W, zirconia, RHEED, TOF-SIMS

\section{1.は じめに}

電子顕微鏡をはじめとする電子線照装置は近年のナノ テクノロジーを支える基盤装置であり ${ }^{1)}$, 学術研究のみ ならず産業応用にも広く用いられている。これらの装置 性能は電子照射系の最上流に位置する電子源の性能に依 存する。そのため, 冷陰極電界放出電子源 (Cold Field emitter : CFE $)^{2 \sim 4)}$, 熱電子源 ${ }^{5)}$, ショットキー型熱電界 電子源 (Schottky emitter : SE) ${ }^{6,7)}$ などが用途に応じ使用 されている。各電子源から発せられる電子線の主な特徴 は, CFE は輝度が高く, 単色であること, 熱電子源は 安定に大電流を得られること, SE はこれらの性能を高 いレベルで両立することなどがある。SE は Fig. 1 に示 すように先端を電解研磨したタングステン（W）のチッ プ表面をジルコニウム酸化物（Zr, O ）で被覆した構造 が 1970 年代に Swanson らによって開発され ${ }^{8,9)}$, 現在も この材料が使われて続けている。 $1800 \mathrm{~K}$ 程度に加熱す ると $\mathrm{Zr}$ と O が $\mathrm{W}$ の表面を熱拡散し, 被覆する。チッ

\footnotetext{
†第 34 回表面科学学術講演会（2014 年 11 月 6 日〜8 日) にて発表

E-mail : soichiro.matsunaga.vs@hitachi.com
}

プ先端には (001)，（110)，（211）, 面方位の定義できな い曲面が現れるが, Zr, O の被覆により(001)面の仕事 関数が選択的に $4.7 \mathrm{eV}$ から $2.8 \mathrm{eV}$ まで低下し ${ }^{6 \sim 10)}$, 引 出電極によって生じる電界がチップ先端に集中すること でこの低仕事関数面から電子が引き出される ${ }^{11)}$ 。しか し, この選択的仕事関数低下メカニズムは不明な点も多 い。その主な理由は, 実際の電子源先端は直径 $1 \mu \mathrm{m}$ 程 度の極小領域であり, さらに動作温度である $1800 \mathrm{~K} も$ の高温状態分析が困難であったためである。 (a)

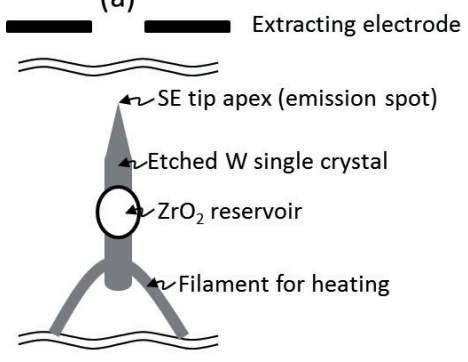

(b)

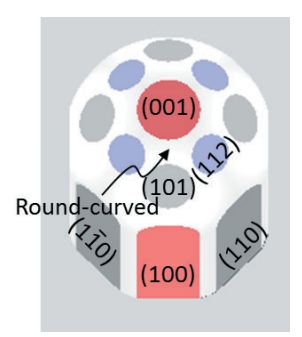

Fig. 1. (color online). (a) Schematic of Schottky emitter tip, (b) Schematic of crystal structures of the emitter tip apex. (From Ref. 12, with permission) 
1990 年代に志水ら ${ }^{13 \sim 15)}$ ，佐藤ら ${ }^{16,17)}$ によって Reflective high-energy electron diffraction (RHEED) や Low energy electron diffraction（LEED）を用いて，よく規定 された単結晶 $\mathrm{W}(001)$ を基板とし, Zr を蒸着した後, 酸 化処理された表面の周期構造の研究が行われた。彼らは $1000 \mathrm{~K} \sim 1400 \mathrm{~K}$ の間で $\mathrm{c}(4 \times 2)+\mathrm{c}(2 \times 4)$ 超構造が $\mathrm{p}(1 \times 1)$ に相転移し ${ }^{13 \sim 16)}$, この転移と同時に仕事関数が 低下することを報告した ${ }^{14,15)}$ 。現在期待されていること は, この仕事関数低下メカニズムを解明するために, 実 際の電子源表面を直接分析し単結晶基板が電子源表面の 現象を再現していることの妥当性を示すこと, $\mathrm{Zr}, \mathrm{O}$, $\mathrm{W}$ 間の結合状態を調べその構造を明らかにすること, 電子源表面に現れる (100)，（110)，（211）面のうち(100) 面の仕事関数のみが選択性に低下する要因を調べること などがある ${ }^{18 \sim 21) 。 ~}$

そこで本報告では, 以下 2 点に関する研究結果を紹介 する。初めに, RHEED 装置を改良することで, 動作温 度状態にある実際のショットキー電子源表面を直接観察 した。次に, Auger electron spectroscopy (AES) と Time of flight-secondary ion mass spectroscopy（TOF-SIMS）を 用い $\mathrm{Zr} / \mathrm{O} / \mathrm{W}(100),(110),(211)$ のそれぞれの表面に おける Zr，O，W の結合状態を調べた。TOF-SIMS では 二次イオン化初期速度に注目することで各イオンの発生 サイトについて考察した。これらの結果に基づき, 電子 源表面の構造モデルを提案する。

\section{2. 実 験 方 法}

\section{1 測定試料}

測定には 2 種類の $\mathrm{Zr} / \mathrm{O} / \mathrm{W}$ 試料を用いた。一つは実 際のショットキー電子源（以下チップ）であり，もう一 つは板状単結晶（以下板状試料）である。実験ではどち らの試料も $1700 \mathrm{~K}$ まで加熱し, 温度はパイロメーター （Keller HCW GmbH, Germany）を用いて測定した。チッ プは RHEED 測定に用い, 実際の電子源動作時と同じょ うに $\mathrm{ZrO}_{2}$ から熱拡散させることで $\mathrm{Zr} / \mathrm{O} / \mathrm{W}$ 表面を作製 した。チップの作製に関する詳細は既報に記す ${ }^{22)}$ 。測定 した面は Fig. 1（b）に示される電子源側面の (100) と (110)面である。一般的な電子線照射装置では先端の (001) 面から放出される電子線を用いるが, bcc 構造を 持つWでは (001) 面はこの面と直交した面（たとえば (100)面）と等価であり, 実際にこれらの面からも電子 放出が起こる。そのため, 測定面は側面の (100)面とし た。この面と比較するため, 電子放出が起こらないつま りは仕事関数が低下しない面として (110) 面も測定した。 板状試料 (Mateck GmbH, Germany) は AES と TOFSIMS 分析に用い, 試料の調整はチップと同じく焼結

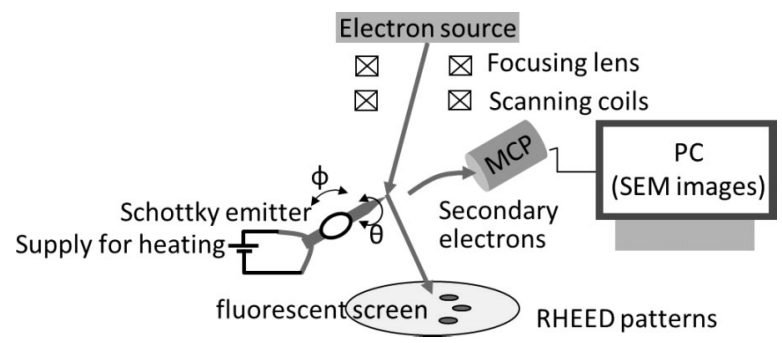

Fig. 2. A schematic of improved RHEED equipment for tip.

$\mathrm{ZrO}_{2}$ からの加熱拡散により行った。試料サイズは 17 (長さ) $\times 1$ (幅) $\times 0.3$ (厚さ) $\mathrm{mm}$ であり, 試料の端 5 $\mathrm{mm}$ の位置に $\mathrm{ZrO}_{2}$ が焼結してある。試料のラフネスは $0.03 \mu \mathrm{m}$ 以下であり, 面方位精度は $0.1^{\circ}$ 以内である。

\subsection{RHEED}

本研究では高温に加熱したチップの回折パターンを直 接測定するため, Fig. 2 に示す 2 点の改良を行った。ま ずは加熱用電流をチップに通電するためのサンプルホル ダーを作製した。次に電子ビームを $20 \mathrm{~nm}$ まで収束す るための電磁レンズと可視化をするための電子ビーム偏 向走査コイルとマルチチャネルプレートを設置する ${ }^{23)}$ とで, チップ先端の走査電子顕微鏡像を取得し, サブマ イクロメートルの領域しか持たないチップ先端にビーム を的確に照射できるようにした。(100)面と（110）面を測 定したときのビームの入射方向はそれぞれ〈0 $\overline{1} 0\rangle$ と $\langle 1 \overline{1} 0\rangle$ であり，20 keV に加速した電子を 4 で入射した。 また, チップの設置角度を正確に決めるために, チップ を 2 軸に精密回転可能な機構を導入した。また, 加熱し たチップからは強い熱放射が起こるため, 蛍光板で検出 した RHEED パターンはこの光に埋もれてしまう。そこ で画像処理技術を用いて, 熱放射によるバックグラウン ドを差し引くことで加熱チップからの RHEED パターン を取得した。

\section{3 AES}

板状試料をPHI670 Auger Nano probe (Perkin Elmer Inc.) を用いて測定した。一次電子の加速は $10 \mathrm{keV}$, 電 流量は $10 \mathrm{nA}$, 測定時間は $40 \mathrm{msec} て ゙$ 測定を行った。必 要な $\mathrm{S} / \mathrm{N}$ 比を確保するため 20 回の積算を行った。

\subsection{TOF-SIMS}

板状試料を TOFLAS-3000（Pascal Co., Ltd., Japan）を 用いて測定した。一般的な TOF では高い質量数分解能 を達成するためにイオン化の初期速度を相殺, もしくは 実質的に無効化できる光学系を構築する ${ }^{24)}$ 。しかし, 本 測定では初期速度を含んだ飛行時間デー夕を取得し, そ こから初期速度を抽出することでイオン化の初期速度に ついて議論を行った。もし二次イオンが初期速度を持て ば，飛行時間は想定されるよりも短くなるため, TOF- 


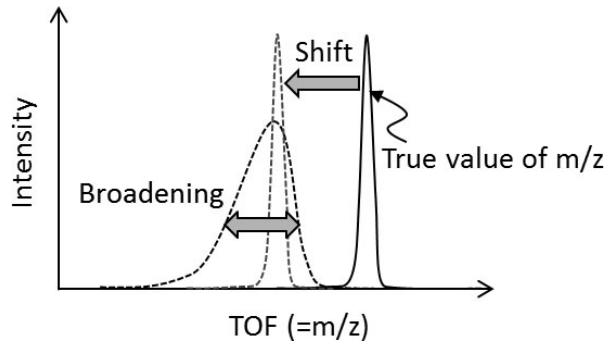

Fig. 3. Schematic of shift and broadening of $\operatorname{TOF}(\mathrm{m} / \mathrm{z})$ spectra caused by the initial velocity and its distribution of secondary ions. (From Ref. 12, with permission)

SIMS のスペクトルは低質量数側にシフトする。また初 期速度が分布を持てば，スペクトルのピークはブロード になる。イオン化時の初期速度によるピークのシフトと ブロード化の概念図を Fig. 3 に示す。シフトとブロード ニングの大きさは TOF 装置の寸法および二次イオンの 加速電圧に依存する。初期速度に関する詳細な議論は結 果と考察の項で行う。

スパッタに用いる一次粒子ビームは $3 \mathrm{kV} に$ 加速した $\mathrm{Ne}$ 原子を用いた。ビームによる照射ダメージを抑えた Static 条件で測定を行うため, 粒子ビーム径は $3 \mathrm{~mm}$, ビーム量は $4 \mathrm{pA}$ とした。この条件において一回の測定 でスパッタされる表面原子の割合は $10^{-9}$ 台と見積もら れ, 十分にStaticな条件とみなせる。本報告で示す TOF-SIMS スペクトルでは飛行時間を質量電荷比 $(\mathrm{m} / \mathrm{z})$ に換算してある ${ }^{25,26)}$ 。換算には表面コンタミである $\mathrm{H}^{+}$, $\mathrm{CH}_{3}{ }^{+}, \mathrm{C}_{3} \mathrm{H}_{\mathrm{x}}{ }^{+}(\mathrm{x}=3,5,7)$ のピークを用い, それぞ れの $\mathrm{m} / \mathrm{z}$ は $1.01,15.02,39.02,41.04,43.06$ である。

\section{3. 結 果 と考察}

\section{1 実電子源における RHEED 測定結果}

Fig.4（a）に室温のチップ(100)面から得られた RHEED パターンを示す。強いスポットは 0 次および 1 次のラウエゾーン上のスポットであり, これらの間に三

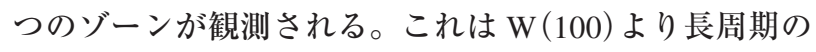
超構造が形成されていることを示しており，このパター ンを詳細に解析すると $\mathrm{c}(4 \times 2)+\mathrm{c}(2 \times 4)$ のダブルドメ イン構造をしていることがわかった。また Fig.4（b） に（a）の０次ラウエゾーンを拡大したパターンを示す。 白矢印は W $(100)$ の格子からの回折スポットであり, 黒 矢印は超構造からの回折スポットである。この状態で試 料を加熱し， $1700 \mathrm{~K}$ で得られたパターンを Fig.4（c) に示す。超構造からのスポットが消えており, $\mathrm{p}(1 \times 1)$ 構造に転移したことがわかる。この構造転移は既報の $\mathrm{W}(100)$ 単結晶試料に Zr を蒸着し酸化調整した試料でも 報告されている ${ }^{14,15,27)}$ 。このことから, チップ試料であ
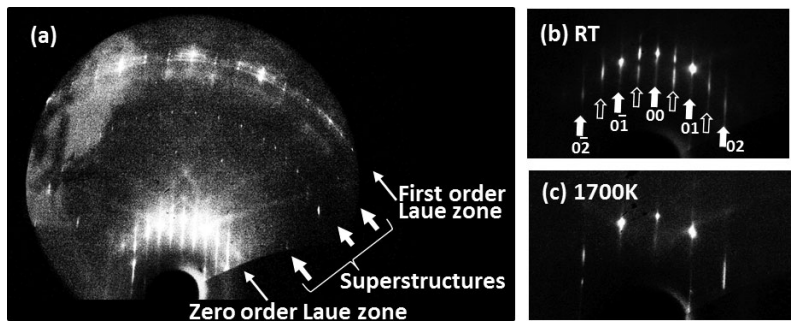

Fig. 4. RHEED patterns from (100) on actual SE tip (a) Zr/ $\mathrm{O} / \mathrm{W}(100)$ at room temperature, (b) Zoom up image of (A) in Zero order Laue zone, and (c) After heated up to $1700 \mathrm{~K}$. (From Ref. 12, with permission)
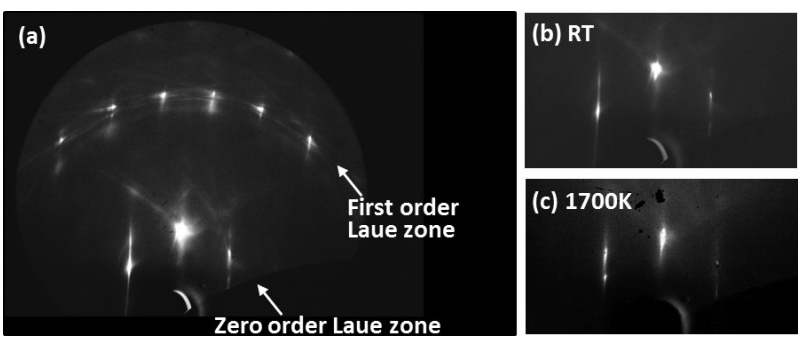

Fig. 5. RHEED patterns from (110) on actual SE tip (a) Zr/ $\mathrm{O} / \mathrm{W}(110)$ at room temperature, (b) Zoom up image of (A) in Zero order Laue zone, and (c) After heated up to $1700 \mathrm{~K}$. (From Ref. 12, with permission)

る $\mathrm{Zr} ， \mathrm{O}$ を熱拡散で被覆した $\mathrm{W}$ と $\mathrm{Zr}$ を蒸着酸化する ことで調整した W 板状試料とで同じ現象が起こってい ることが示され, 板状試料をチップの模擬試料として用 いることが妥当であると結論できる。

Fig.5（a）に室温のチップ(110) 面から得られた RHEED パターンを示す。0 次および 1 次のスポットし か観測されず, $\mathrm{Zr} / \mathrm{O} / \mathrm{W}(110)$ では $\mathrm{p}(1 \times 1)$ 構造が形成さ れているといえる。Fig. 5（b）に（a）の０次ラウエソ ーンを拡大したパターン, Fig. 5 (c) に $1700 \mathrm{~K}$ に加熱 したときのパターンを示す。すべての温度で $\mathrm{p}(1 \times 1)$ 構 造が保たれていることがわかる。これらの RHEED 測定 結果と電子放出の事実から, Zr/O/W (100) 面では $\mathrm{p}(1 \times 1)$ 構造への転移が仕事関数の低下と同時に起こっ ているが，(110)面では $\mathrm{p}(1 \times 1)$ 構造を取っていても仕 事関数の低下が起こっていないことがわかる。この結果 は, 周期構造や表面被覆率から単純に仕事関数低下につ いて議論することはできないことを意味している。

\section{$3.2 \mathrm{Zr} / \mathrm{O} / \mathrm{W}(001) ，(110) ， （ 211) の \mathrm{AES}$ 測定結果}

Fig. 6 (a) にジルコニアを焼結, 拡散させた W(001), (110)，（211）試料および清浄な W(001) 試料から得られ た AES スペクトルを示す。各スペクトルは縦軸に沿っ て平行移動しているが，スペクトル強度の規格化は行っ ていない。Fig.6（b）は（a）を拡大したスペクトルで ある。すべての試料のスペクトルに W 由来の 130 , 
(a)

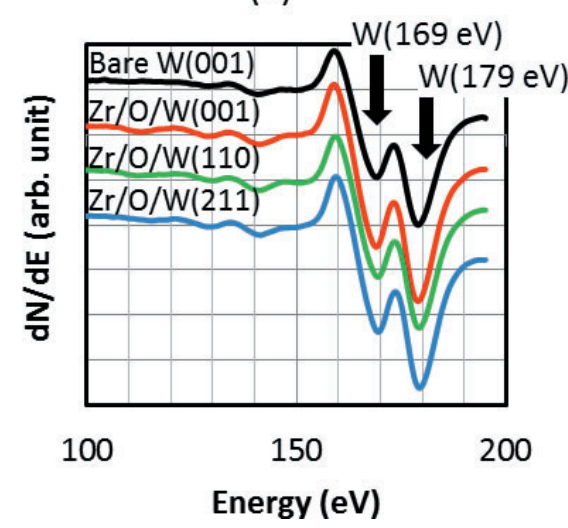

(b)

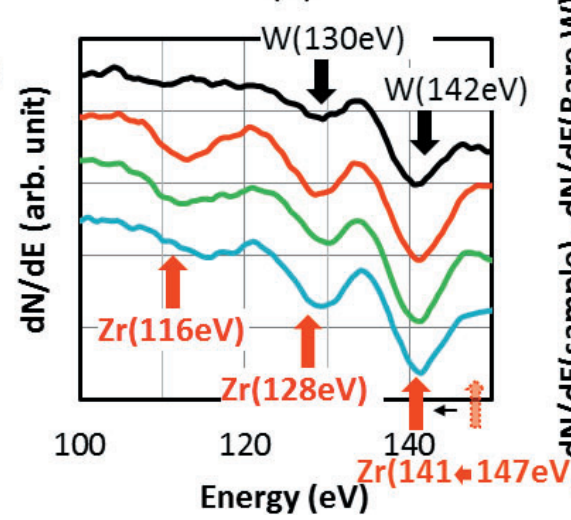

(c)

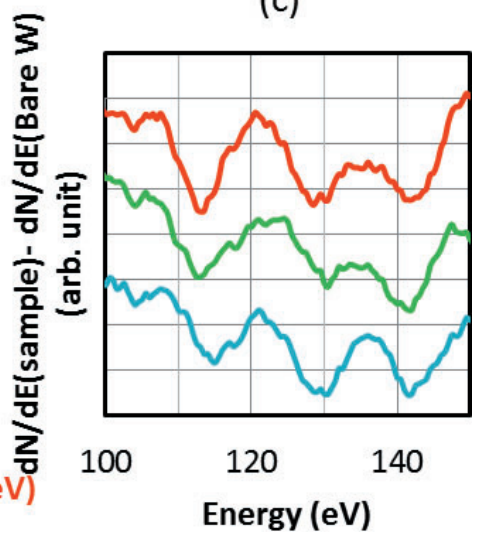

Fig. 6. (color online). AES spectra of Bare $\mathrm{W}(001), \mathrm{Zr} / \mathrm{O} / \mathrm{W}(001), \mathrm{Zr} / \mathrm{O} / \mathrm{W}(110), \mathrm{Zr} / \mathrm{O} / \mathrm{W}(211)$ at room temperature (a) Range : 100 $200 \mathrm{eV}$, (b) Zoom up of (A), and (c) Difference spectra between each sample and Bare W. (From Ref. 12 , with permission)

142, $169,179 \mathrm{eV}$ のピーク ${ }^{28}$ が観測された。一方, $\mathrm{Zr}$ 由来のピークは $116,128,147 \mathrm{eV}$ の位置に現れると期 待される ${ }^{28)}$ 。Fig. 6 (b) に示されるように, $116 \mathrm{eV}$ のピ ークが $\mathrm{Zr} / \mathrm{O} / \mathrm{W}(001), \quad(110), \quad(211)$ の各試料で観測さ れ，清浄な $\mathrm{W}(001)$ 試料からは観測されなかった。この 結果から Zr は面方位にかかわらず，すべての面に搪散 しているといえる。 $\mathrm{Zr}$ の $128 \mathrm{eV}$ のピークはW の 130 $\mathrm{eV}$ のピークと重なっているため，このピーク強度が増 加している。 $\mathrm{Zr}$ の $147 \mathrm{eV}$ のピークはすべての試料で観 測されなかったが，このピークは $\mathrm{Zr}$ が酸素と結合する と $141 \mathrm{eV}$ にシフトすることが知られている ${ }^{29)}$ 。つまり W の $142 \mathrm{eV}$ のピークと重複していると考えられる。そ こで, W との重複分を差し引くため, 各スペクトルに ついて清浄な W との差スペクトルを求めた。その結果 を Fig. 6 (c) に示す。116，128，142 eV のピークが明 瞭に観測された。この結果から Zr とO はすべての面方 位に拡散しており，Zr は $\mathrm{O}$ と結合していると結論付け ることができる。

\section{$3.3 \mathrm{Zr} / \mathrm{O} / \mathrm{W}$ (001)，（110)，（211）の TOF-SIMS 測 定結果}

Fig. 7 (a) に Zr/O/W (001)，(110)，(211) から得ら れたTOF-SIMS 結果を示す。すべてのスペクトルで $m / z=91$ と 105 付近にピークが観測された。これらは $\mathrm{Zr}^{+}$と $\mathrm{ZrO}^{+}$のピークと考えられる。ここで $\mathrm{Zr}$ は 90, 91，92，94，96の安定同位体を持つが，今回用いた装 置では初期速度を相殺しないことからそれぞれの同位体 を見分けるだけの分解能がなく $\mathrm{Zr}$ の平均質量数 91.22 の近くにピークが現れたと考えられる。一方, $\mathrm{ZrO}^{+}$は $m / z=107$ にピークを持つと考えられるが，105にピー クが観測された。また，このピークは $\mathrm{Zr}^{+}$の $m / z=91$ のピークよりもブロードになっている。このシフトおよ
びブロード化は 2.4 節で述べたようにイオン化時の初期 速度によると考えられる。Fig. 7 (b) に $m / z$ が 150 から 240 までの TOF-SIMS スペクトルを示す。すべてのスぺ クトルで二つのブロードなピークが観測され，低質量数 側のピークは $\mathrm{W}^{+}$, 高質量数側のピークは $\mathrm{WO}^{+}$である と考えられる。W の安定同位体は 182，183，184，186 であり平均質量数は 183.8 であることから，これらのピ ークは明らかにシフトおよびブロード化している。つま りイオン化時に初期速度を持っていると考えられる。

そこで, 得られたスペクトルから各イオンの初期速度 を計算した。ここで飛行時間 $t_{f i g h t}$ は次式で表される。

$$
t_{f i g h t}=\sqrt{\frac{2 M l_{a}^{2}}{e N V^{2}}}\left(\sqrt{E_{0}+V}-\sqrt{E_{0}}\right)+l_{d} \sqrt{\frac{M}{2 e N\left(E_{0}+V\right)}}
$$

ここで, $M$ は $m / z, m$ はイオンの質量数, $z$ は価数, $V$ は加速電圧, $E_{0}$ は初期速度, $l_{a}$ は加速距離, $l_{d}$ はドリ フト距離, $e$ は電気素量, $N$ はアボガドロ数である。本 実験では $l_{a}=0.015 \mathrm{~m}, l_{d}=0.38 \mathrm{~m}, V=2.0 \mathrm{kV}$ で一定で ある。つまり, $M$ は $t_{f i g h t}$ と $E_{0}$ の関数としてあらわされ る。ここで $M$ すなわちイオン種を仮定すれば， $t_{f i g h t}$ を 測定することで，初期速度を求めることができる。上式 と Fig. 7（a)，（b）のスペクトル測定結果を用いて計算 した $\mathrm{Zr}^{+}, \mathrm{ZrO}^{+}, \mathrm{W}^{+}, \mathrm{WO}^{+}$初期速度分布を Fig. 7 (c) に示す。 $\mathrm{Zr}^{+}$は数 $\mathrm{eV}$ の初期速度しか持たないが, $\mathrm{ZrO}^{+}, \mathrm{W}^{+}, \mathrm{WO}^{+}$は $20 \mathrm{eV}$ 程度をピークとした初期速 度を持つことがわかる。

スパッタされた二次イオンの初期速度分布については 理論 ${ }^{30)}$ および実験 ${ }^{31,32}$ が報告されており, 表面吸着層か ら発生した二次イオンの初期速度は数 $\mathrm{eV}$ 程度と小さい が, 表面吸着物ではない，たとえば結晶構成物では数十 $\mathrm{eV}$ 程度と大きく，その分布が広いことが報告されてい る。これらの報告と, Fig. 7 (c) の初期速度分布から考 
(a)

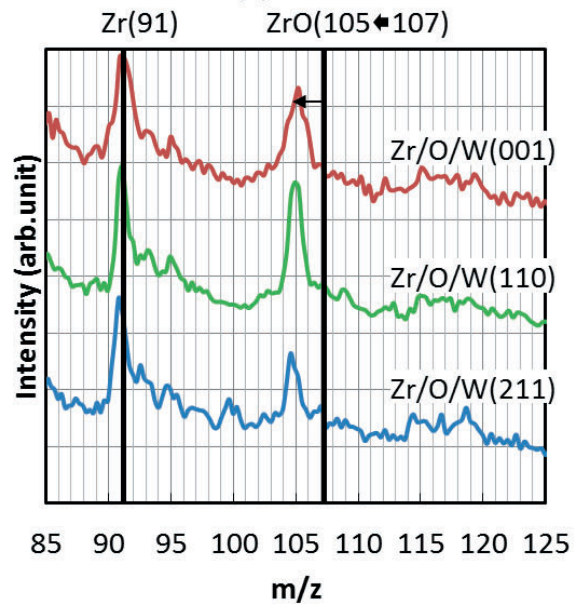

(b)

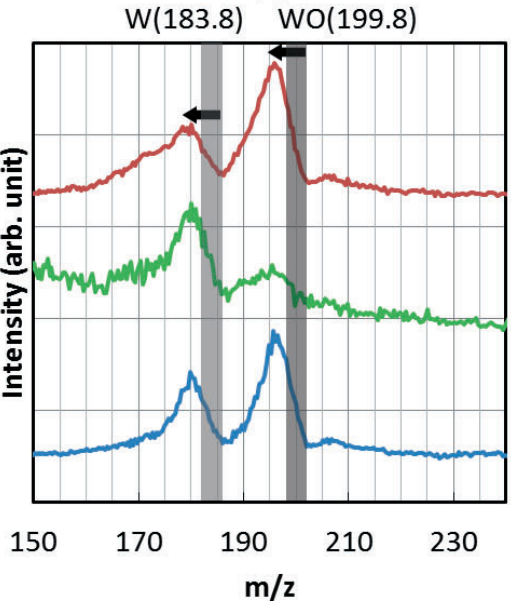

(c)

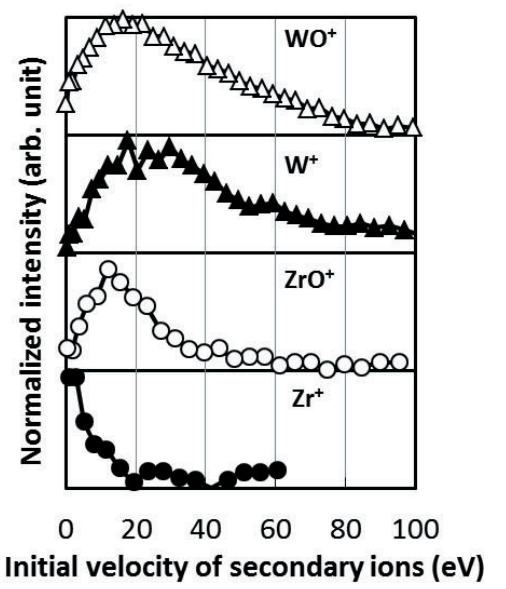

Fig. 7. (color online). (a), (b) TOF-SIMS spectra of $\mathrm{Zr} / \mathrm{O} / \mathrm{W}(001),(110)$, and (211) (c) Distributions of initial velocity of each ions from the $\mathrm{Zr} / \mathrm{O} / \mathrm{W}(001)$ surface. (From Ref. 12, with permission)

(a)

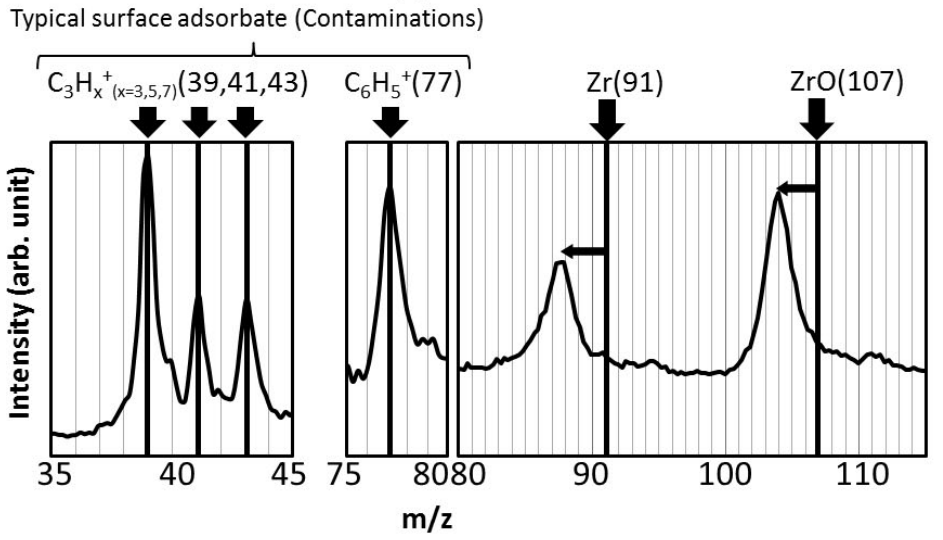

(b)

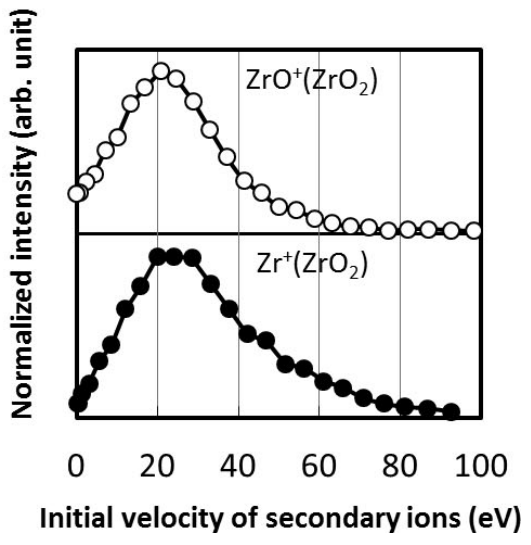

Fig. 8. (a) TOF-SIMS spectrum of $\mathrm{ZrO}_{2}$ crystal and (b) distributions of initial velocity of $\mathrm{Zr}^{+}$and $\mathrm{ZrO}^{+}$. (From Ref. 12, with permission)

えると，Zr は表面吸着物であるが，ZrO，W，WO は表 面吸着物ではないと考えることが妥当である。

本結果の妥当性をより確実なものとするために, $\mathrm{ZrO}_{2}$ 結晶の TOF-SIMS 分析を行った。 $\mathrm{ZrO}_{2}$ の結晶では $\mathrm{Zr}^{+}$も $\mathrm{ZrO}^{+}$も結晶構成物であり, 表面吸着物ではない ためどちらのイオンも $20 \mathrm{eV}$ 程度の初期速度を持つと期 待される。測定結果を Fig. 8 (a) に示す。 $\mathrm{Zr}^{+}, \mathrm{ZrO}^{+}$ どちらのピークもシフトかつブロード化していることが わかる。一方, Fig. 8（a）中には表面吸着コンタミネー ションである炭化水素群のピークも観測されるが，これ らのピークはシフトしていない。このスペクトルから計 算した各イオンの初期速度の分布を Fig. 8（b）に示す。 $\mathrm{Zr}^{+}$も $\mathrm{ZrO}^{+}$も $20 \mathrm{eV}$ 程度の初期速度を持っていること がわかる。このことから, $\mathrm{Zr} / \mathrm{O} / \mathrm{W}$ の表面では $\mathrm{Zr}$ は最 表面吸着物として存在するが， $\mathrm{ZrO}, \mathrm{W}, \mathrm{WO}$ は表面吸 着物ではないと結論付けることができる。

\section{$3.4 \mathrm{Zr} / \mathrm{O} / \mathrm{W}$ 表面構造モデル}

本研究で得られた AES および TOF-SIMS 実験結果か ら $\mathrm{W}$ と $\mathrm{Zr}$ の状態および構造をまとめると以下のように なる。 $\mathrm{W}$ は基板である単結晶以外にも $\mathrm{W}$ 酸化物層とし て存在する。 Zr は最表面層に吸着物として存在し, す べての Zr が Zr-O 構造体を形成している。ただし $\mathrm{Zr}$ は 表面吸着物であるが $\mathrm{Zr}-\mathrm{O}$ 構造体は表面吸着物ではない ため $\mathrm{W}$ 酸化物結晶を構成している $\mathrm{O}$ 原子の上に $\mathrm{Zr}$ が 吸着していると考えることが妥当である。これらの結果 を基に Fig. 9 に示すモデルを提案する。基板である W 単結晶上に W 酸化物層が形成され，この W 酸化物を構 成する $\mathrm{O}$ 原子の上に $\mathrm{Zr}$ が吸着している。

\section{4. ま と め}

$\mathrm{Zr} / \mathrm{O} / \mathrm{W}$ ショットキー熱電界電子源の表面構造を調べ るために，RHEEDを用いて実際の電子源（チップ）表 


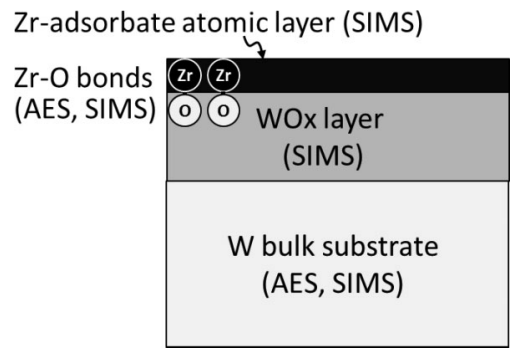

Fig. 9. Proposed model of $\mathrm{Zr} / \mathrm{O} / \mathrm{W}$. (From Ref. 12, with permission)

面に現れる (100) 面と (110) 面を直接観測した。またチッ プを加熱することで室温から動作温度である $1700 \mathrm{~K}$ ま での表面周期構造を調べた。また, AES と TOF-SIMS を用いて (100)，(110)，（211）面での Zr，O，W の結合 状態を調べた。その結果以下のことがわかった。

（1）実際のチップ表面に現れる $\mathrm{Zr} / \mathrm{O} / \mathrm{W}$ (100) 面で は $1700 \mathrm{~K}$ に昇温することで表面周期構造が $\mathrm{c}(4 \times 2)+$ $\mathrm{c}(2 \times 4)$ 構造から $\mathrm{p}(1 \times 1)$ 構造に転移する。この結果は $\mathrm{Zr}$ を蒸着酸化して作製した $\mathrm{W}$ 板状単結晶試料と同じで あり, 板状試料は実際のチップの模擬として妥当であ る。一方, $\mathrm{Zr} / \mathrm{O} / \mathrm{W}(110)$ 面では温度に依存せず $\mathrm{p}(1 \times 1)$ 構造をとる。

（2）AES 測定結果から, Zr は W (001), (110), (211)のすべての面に拡散して扔り，Zr は O と結合して いる。

（3） TOF-SIMS 測定結果から， Zr は表面吸着層とし て存在している。この $\mathrm{Zr}$ は Zr-O 構造体を形成している が, $\mathrm{Zr}-\mathrm{O}$ は $\mathrm{W}$ 表面上の吸着物ではなく, $\mathrm{W}$ 酸化物層を 構成している O に Zr が吸着している。

\section{謝 辞}

(株) 日立製作所中央研究所の土井隆久博士には RHEED とAES 測定結果について議論をいただきまし た。(株) Pascal の中西繁光博士, 長澤裕樹氏には TOFLAS-3000での測定に協力いただきました。また, 志水隆一博士, 永富隆清博士, 飯田真一博士, 田村圭司 博士にはショットキー型電子源の表面研究の経緯につい て御教示いただき，有益な御助言をいただきました。各 氏に感謝いたします。

\section{文献}

1) L. Reimer: "Scanning Electron Microscopy: Physics of Image Formation and Microanalysis" (Springer, 1985).

2) R. Gomer : "Field emission and field ionization" (American Institute of Physics, New York, 1993).
3) A. Crewe, D. Eggenberger, J. Wall and L. Welter : Rev. Sci. Instrum. 39, 576 (1968).

4) K. Kasuya, S. Katagiri, T. Ohshima and S. Kokubo : J. Vac. Sci. Technol., B 28, L55 (2010).

5) M.E. Haine and P.A. Einstein : J. Appl. Phys. 3, 40 (1952).

6) L.W. Swanson: "Handbook of charged particle optics" ed. by J. Orloff (CRC press, 2008) p. 77.

7) H. Kim, M. Yu, M. Thomson, E. Kratschmer and T. Chang: J. Appl. Phys. 81, 461 (1997).

8) L. Swanson and L. Crouser: J. Appl. Phys. 40, 4741 (1969).

9) L. Swanson : J. Vac. Sci. Technol. 12, 1228 (1975).

10) L. Danielson and L. Swanson : Surf. Sci. 88, 14 (1979).

11) M. Fransen, J. Faber, T.L. van Rooy, P. Tiemeijer and P. Kruit : J. Vac. Sci. Technol., B 16, 2063 (1998).

12) S. Matsunaga and S. Katagiri : Surf. Sci. 633, 82 (2015).

13) S. Lee, Y. Irokawa, M. Inoue and R. Shimizu : Surf. Sci. 365, 429 (1996).

14) R. Shimizu : J. Electron Microsc. 47, 371 (1998).

15) Y. Irokawa, R. Mitsuhashi, S. Lee, Y. Kimura, M. Inoue, Y. Takai and R. Shimizu : Surf. Sci. 367, 96 (1996).

16) H. Satoh, H. Nakane and H. Adachi : Appl. Surf. Sci. 94, 247 (1996).

17) H. Satoh, S. Kawata, H. Nakane and H. Adachi : Surf. Sci. 400, 375 (1998).

18) K. Liu, G. Schwind, L. Swanson and J. Campbell : J. Vac. Sci. Technol., B 28, C6C26 (2010).

19) A. Bahm, G. Schwind and L. Swanson : J. Appl. Phys. 110, 054322 (2011).

20) M. Bronsgeest and P. Kruit : Ultramicroscopy 110, 1243 (2010).

21) S. Kawata, S. Tahara, H. Satoh, H. Nakane and H. Adachi : Appl. Surf. Sci. 111, 96 (1997).

22) H. Nishiyama, T. Ohshima and H. Shinada : Appl. Surf. Sci. 146, 382 (1999).

23) M. Ichikawa, T. Doi, M. Ichihashi and K. Hayakawa : Jpn. J. Appl. Phys. 23, 913 (1984).

24) M. Toyoda, D. Okumura, M. Ishihara and I. Katakuse : J. Mass Spectrom. 38, 1125 (2003).

25) A. Cameron and D. Eggers : Rev. Sci. Instrum. 19, 605 (1948).

26) W. Wiley and I.H. McLaren : Rev. Sci. Instrum. 26, 1150 (1955).

27) K. Tamura, M. Amano, W. Chu, H. Ishii, M. Owari, T. Kawano, T. Nagatomi, Y. Takai, C. Oshima and R. Shimizu : Surf. Interface Anal. 37, 217 (2005).

28) L. Davis : "Handbook of Auger Electron Spectroscopy" (Physical Electronics Industries, 1976).

29) J.M. Sanz, C. Palacio, Y. Casas and J.M. MartinezDuart : Surf. Interface Anal. 10, 177 (1987).

30) Z. Sroubek : Surf. Sci. 44, 47 (1974).

31) S. Taya : Mass Spectroscopy 26, 89 (1978).

32) T. Ishitani, H. Tamura and T. Shinmiyo : Surf. Sci. 55, 179 (1976). 